\title{
ТРАНСФОРМАЦІЙНІ ПРОЦЕСИ НА ТЕРНОПІЛЬЩИНІ В 1939-1941 РОКАХ ЯК ФАКТОР ФОРМУВАННЯ У СТУДЕНТІВ-МЕДИКІВ ПОЧУТТЯ ПАТРІОТИЗМУ, КОМПЕТЕНТНОСТІ ПІД ЧАС ВИВЧЕННЯ ІСТОРІЇ КРАЮ
}

\author{
ДВНЗ «Тернопільський державний медичний університет імені І. Я. Горбачевського МОЗ України», \\ м. Тернопіль, Україна
}

\begin{abstract}
Мета: шляхом аналізу суспільно-політичних та соціально-економічних трансформаційних процесів на Тернопільщині в 1939-1941рр. та їх наслідків фрормувати у студентів-медиків почуття патріотизму, компетентності під час програмного вивчення новітньої історії України.

Матеріали і методи. На основі історико-порівняльного та бібліосемантичного методів проведено систематичний аналіз наукових джерел вітчизняних дослідників та істориків діаспори, архівних матеріалів щодо інсрормації про події передвоєнного періоду на території Тернопільщини.

Результати. У запропонованій статті авторами розкрито природу та мотиви нової радянської влади, яка збройно вступила на територію Західної України 17 вересня 1939 р. і шляхом насилля запроваджувала свої ресрорми місцевому населенню. Встановлено, що думки дослідників розходяться в трактуванні визвольного походу Червоної армії на захід та виявлено взаємозв'язок загальнодержавних і регіональних чинників радянізації Тернопільщини.

Висновки. Авторами зроблено власний внесок у розкриття мотивів та наслідків діяльності тодішньої радянської влади на території краю.
\end{abstract}

КЛЮчОВІ СЛОВА: Західна Україна; Тернопільщина; радянська влада; культура; режим, окупація.

У новітній історії Західної України періоду 1939-1941 рр. належить особливе місце. За цей час західноукраїнське населення зазнало гніту трьох окупаційних режимів: польського, радянського і німецького. Упродовж цих років воєнні дії Другої світової війни на землях Західної України розпочиналися тричі: на початку вересня 1939 р. німецька авіація бомбила волинські міста; 17 вересня розпочалась так звана «визвольна місія» Червоної армії, внаслідок чого регіон приєднали до УРСР у складі СРСР; наприкінці червня - на початку липня 1941 р. розпочались масштабні бої між радянськими і гітлерівськими військами. Цей період вивчають студенти I курсу медичного факультету з історії України на четвертому практичному занятті, мета якого - зберегти наратив і в масштабах однієї локальної одиниці показати масштаби радянської тоталітарної системи.

Таким чином, на першому етапі Другої світової війни (до початку радянсько-німецького воєнного зіткнення із вторгненням фашистських військ на територію СРСР) західноукраїнські землі стали геограсрічним і політичним простором геополітичного протистояння наймогутніших на той час гітлерівської і сталінської тоталітарних систем. Суть подій 1939-1941 рр. полягала в тому, що внаслідок Пакту Молотова-Ріббентропа і таємних

(с Л. В. Кравчук, Т. Б. Кадобний, Л. О. Кравчук, 2018 протоколів до нього із застосуванням збройної сили та в ході військової агресії було здійснено поділ Польщі між Берліном і Москвою, а Західна Україна приєднана до УРСР.

3 метою здійснення процесів радянізації та форсування унісрікації суспільно-політичного і соціально-культурного життя регіону на принципах сталінського тоталітарного режиму новій окупаційній владі довелося застосувати комплекс політико-правових заходів, які з однієї сторони створювали умови радянізації краю, а з іншої надавали кремлівському сценарію соціалістичної транссрормації всіх сорер західноукраїнського суспільства легітимного, насамперед із позицій міжнародного права, характеру.

Ідеологічний акцент радянської політики зміщувався на тезу про повну відповідність приєднання Західної України до УРСР прагненням місцевого населення, і цим самим приховувались дійсні наміри Москви у вересневій акції 1939 р. та істинні мотивації анексії західноукраїнських земель, які насправді були спрямовані не на гарантування демократичного і соціалістичного майбутнього західних українців, а на забезпечення агресивних стратегічних інтересів кремлівського керівництва радянізації.

Мета дослідження: шляхом аналізу суспільнополітичних та соціально-економічних трансфрорма- 
ційних процесів на Тернопільщині в 1939-1941 рр. та їх наслідків фрормувати у студентів-медиків почуття патріотизму, компетентності під час програмного вивчення новітньої історії України.

Матеріали і методи. На основі історико-порівняльного та бібліосемантичного методів проведено систематичний аналіз наукових джерел вітчизняних дослідників та істориків діаспори, архівних матеріалів щодо інформації про події передвоєнного періоду на території Тернопільщини.

Результати дослідження та їх обговорення. Складовою частиною трансформаційних процесів нової окупаційної влади була культура. Перетворення здійснювані радянською владою у всіх сорерах культурного життя західноукраїнського населення мали чітку стратегічну мету: відкрити найширші можливості для формування та розвитку нової культури - соціалістичної за змістом і національної за фрормою. Апробовані в Радянському Союзі принципи культурного будівництва трансформувалися на новий соціально-культурний ґрунт, у нові політико-економічні умови. Радянські дослідники історії партії вважали, що «невід'ємною складовою частиною соціальних перетворень у західних областях поряд із перетвореннями в галузі політичного, економічного і суспільного життя було здійснення культурної революції. Завдання культурної революції вимагали величезного піднесення культурного рівня трудящих, перевиховання їх свідомості на основі пролетарської ідеології та перетворення їх у свідомих творців соціалістичної культури. Культурне будівництво в західних областях вищою мірою полегшувалося тим, що в Радянському Союзі на той час вже була здійснена культурна революція і створена висока соціалістична культура, яка $€$ втіленням ідей марксизму-ленінізму. Трудящі західних областей, зокрема працівники культурного фрронту, могли почерпнути у народів Радянського Союзу досвід культурного будівництва».

Зміст, форми і напрями своєї політики у сфері культури партійно-державні органи фрормували на основі того, що за умов панської Польщі трудящі західноукраїнських земель не мали можливостей для культурного розвитку. Більше того, вважали, що незначна кількість, діючих у ті часи, польських «домів людових», «українських світлиць», читалень «Просвіти» ґрунтувалися на націоналістичних принципах, перебували під впливом українських буржуазних націоналістів і духовенства та «отруювали свідомість трудящих націоналістичним і релігійним дурманом, намагаючись відвернути їх увагу від питань класової боротьби». Тобто радянські історики висвітлюють розвиток соціалістичної культури в західних областях України як процес напруженої боротьби зі звичками і традиціями людей, успадкованими від капіталізму, та 3 найнебезпечнішим породженням капіталістичного суспільства - буржуазним націоналізмом.

Саме 3 цієї причини вже 3 перших днів після приєднання всі існуючі на західноукраїнських землях польські «доми людові», читальні «Просвіти», культурні установи інших національностей, що мали своїм завданням виховання мас у націоналістичному дусі, були закриті, а на їх місце в усіх населених пунктах краю прийшли новостворювані «культурно-освітні установи, багато з яких у найближчому часі перетворилися у справжні вогнища культури і пропаганди ідей комуністичної партії» [8].

Тактика радянізації духовної сфери була аналогічною тактиці радянізації економічної або політичної сорер суспільного життя: ідеологію, спосіб мислення і культурні традиції змінювали швидко, майже за директивними вказівками, як змінювали приватну власність на державну, а багатопартійність - на однопартійність, навіть із застосуванням брутального примусу в шокових дозах. Сталінські ідеологи враховували, що така тактика викликатиме певний супротив, але цей супротив не міг мати зовнішнього соціального вираження, а був лише внутрішнім опором і мав особистісний духовний зміст.

Отже, одним із перших завдань було зламати цей внутрішній особистісний опір, забезпечити своєрідну «радянізацію особистості» через звернення до внутрішньодуховної сорери людини, на яку офріційна пропаганда мала мінімальний, або й не мала ніякого дієвого впливу. У цьому плані партійно-державній владі протистояв могутній відкритий опонент, який здійснював потужний позитивний вплив на внутрішній духовний світ людини, чим стимулював і підтримував духовний опір догматичній комуністичній ідеології, - християнську церкву, непідконтрольну радянському режимові. Церква своєю природою не вписувалась у радянську систему як у соціально-політичному, так і в культурно-духовному аспектах. Саме в релігійній вірі, в церковних богослужіннях знаходили віруючі громадяни (а таких у Західній Україні була абсолютна більшість) порятунок від засилля чужих ідеологічних штампів і від насилля компартійного апарату.

Статистика вказувала на широку базу церковного впливу: 3,5 млн греко-католиків, 2 млн римокатоликів, 1,5 млн православних, 800 тис. іудеїв. 3 метою впливу на ці майже 8 млн українського населення партійно-державна влада розпочала масштабний наступ на всі релігійні конфесії. Ідеологічну основу такого наступу на церкву бачили в реакційній ролі релігії, церкви і священнослужителів у суспільному житті. Влада твердила, що ксьондзи, попи і равини як ворожі елементи активно здійснювали антинародну діяльність, а церква, костьол і синагога спрямовували свої дії проти радянської влади. 
Тому партійні організації західних областей України розгорнули широку антирелігійну пропаганду. За короткий час до Західної України було завезено великі партії атеїстичної літератури, повсюдно організовано читки лекції на атеїстичну тематику. На кінець 1940 р., за звітом Наркомату освіти УРСР, у шести західноукраїнських областях діяли 335 атеїстичних гуртків, які охопили майже 6 тис. чоловік. Атеїстична пропаганда стала обов'язковим елементом навчально-виховного процесу в усіх закладах освіти: вчителі та викладачі були зобов'язані включати до робочих конспектів і текстів лекцій положення, висновки, рекомендації та приклади антирелігійного змісту [3].

Нова окупаційна влада однозначно відносила церкву і духовенство до ворожого антирадянського табору, до контрреволюційних сил. Одним із найважливіших засобів боротьби з такими силами вважали посилення агітаційно-пропагандистської роботи, здійснення планових, правильно політично зорієнтованих культурно-масових заходів серед місцевого населення, що повинно було б дати подвійний ефект: схилити симпатії мешканців міст і сіл до радянської влади та мінімізувати або навіть унеможливити підтримку ними антирадянських акцій.

Показовим у цьому аспекті є рішення Тернопільського обкому КП(б)У від 23 грудня 1939 р. щодо політичного стану в Збаразькому повіті Тернопільської області. Ситуація полягала в тому, що у трьох селах Збаразького повіту (Кобилля, Іванчани, Курники) у ніч з 17 на 18 грудня відбулися «контрреволюційні» виступи селян. У постанові бюро обкому нічого не говориться про дії радянських каральних органів (це залишилося поза протоколом), але детально визначені контрпропагандистські заходи: розгортання масово-політичної роботи у повіті, відрядження до повіту 10 членів ВКП(б) з числа обласного партійного активу, проведення повітових партійних зборів із проблем посилення масово-політичного виховання населення повіту з використанням ресурсів культосвітніх установ тощо [4].

3 цієї постанови випливає, що на агітаційнопропагандистську, культурно-масову роботу в питаннях зміцнення радянської влади на місцях партійно-державні органи покладали не менші надії, ніж на діяльність тодішніх силових структур. Перший висновок, що випливає зі згаданого партійного документа: партійні органи та органи НКВС у радянізації краю діяли в одному напрямі як два фрланги одного фронту, але перший пропагандистськими, а другий - силовими засобами. Другий висновок: партійно-державні органи не відокремлювали культурно-масову роботу від агітаційно-пропагандистської і навпаки. Але так само, як силова структура НКВС підпорядковувалась партійним органам, культурно-масова робота повністю служила агітаційно-пропагандистським цілям. Тобто культура підлягала ідеології як частина цілому, як вторинне первинному.

Таким чином, радянізація культурної сорери суспільного життя набувала фрорми «комунізації» свідомості громадян через ідеологізацію всіх форм і засобів тогочасного культурного процесу на західноукраїнських землях. Посилений акцент на питаннях агітаційно-масової і пропагандистської роботи серед населення краю прослідковується у більшості рішень і постанов, прийнятих партійно-державними органами області в 19391940 рр. У вищезгаданому партійному рішенні бюро Тернопільського обкому КП(б)У вказало Чортківському повітовому комітету партії на незадовільний стан пропагандистської та агітаційномасової роботи серед мешканців повіту: відсутнє навчання активу (пропагандистів, агітаторів, лекторів), незадовільна організація читки лекцій для працівників міста і села (всього 3 лекції на місяць на весь повіт), потрапляння до складу агітаторів і лекторів ворожих елементів (колишніх чиновників, членів ворожих партій), відсутність гуртків із вивчення Сталінської Конституції та роз'яснення населенню рішень партії й уряду. Повітовому комітетові КП(б)У доручено до 1 січня 1940 р. розробити необхідні заходи з усунення вказаних недоліків [4].

Про організацію масово-політичної роботи в повітах доповідали обкому КП(б)У практично всі повітові (згодом районні) партійні комітети. 13 січня 1940 р. це зробили Тернопільський і Борщівський повіткоми КП(б)У і Тернопільський міськком КП(б)У. Бюро обкому констатувало, що в цих повітах зроблено перші кроки в організації масовополітичної роботи серед трудящих: проведено відповідні збори, прочитано ряд лекцій, практикують бесіди з окремими групами працівників, підбирають кадри агітаторів, списки яких подані на затвердження у повітком. Водночас не здійснюють належного керівництва роботою районних газет, не створено гуртків із вивчення Сталінської Конституції та Положення про вибори до Верховної Ради СРСР та Верховної Ради УРСР.

На окремих крупних підприємствах, зокрема на Борщівській тютюновій фрабриці, де працюють більше 300 робітників, не прочитано жодної лекції, не фрункціонують ні клуб, ні бібліотека. Повіткомам і міськкому партії доручено підібрати повноцінні кадри агітаторів, сорормувати агітколективи, визначити і затвердити їх керівників, проводити навчання агітаторів шляхом організації відповідних семінарів і нарад з обміну досвідом роботи, створити гуртки з вивчення Сталінської Конституції, сорормувати при парткомах лекторські групи, на засіданнях бюро райкомів і міськкому партії заслуховувати звіти керівників агітколективів і лекторських груп про пропагандистську і 
масово-політичну роботу на підприємствах, в установах, серед сільського населення.

У цій же постанові Тернопільського обкому КП(б)У знаходимо особливий момент: секретареві Тернопільського повіткому партії доручено провести роз'яснювальну роботу серед селян повіту щодо допущення відповідальними керівниками повіту політичної помилки, яка полягала в організації по селах повіту комітетів незаможних селян. А це означало, що будь-яка масовополітична «самодіяльність», зокрема у створенні несанкціонованих партійними органами громадських об'єднань на місцях, заборонялася [5].

Суперечливою виглядає Постанова Тернопільського обкому КП(б)У від 13 серпня 1940 р. «Про стан пропагандистської та агітаційної роботи в Заліщицькому районі», де зазначається, що політико-масова робота в районі покращилась (проводять лекції, бесіди, співбесіди, наради з обміну досвідом, мітинги тощо), що мобілізує трудящих на виконання політико-господарських завдань, але має місце низка суттєвих недоліків (відсутня допомога низовим колективам зі сторони райкому, не проводять необхідні консультації, не організована робота агітколективів, а окремі 3 них припинили свою діяльність, відсутня увага до групової та індивідуальної агітації, культурномасова робота обмежується лише вечорами художньої самодіяльності у вихідні дні), внаслідок чого в багатьох трудових колективах знижується трудова дисципліна, а в окремих колгоспах колгоспники не виходять на роботу [6].

Такий підхід характерний для багатьох партійних рішень, де позитивний зміст констатуючої частини заперечується критичними зауваженнями і змістом постановляючої частини: спроби видати бажане за дійсне спростовують конкретними вказівками на усунення недоліків, які своєю серйозністю і масштабами виключають попередньо задекларований позитив.

Невисока ефективність, а часто й безрезультативність політико-масової роботи в низових колективах змушує партійні органи постійно повертатись до розв'язування одних і тих же питань, повторно вирішувати одні й ті ж проблеми, що навіть ускладнюється порівняно з їх попереднім станом. Так, у травні 1940 р. бюро обкому КП(б)У вивчало стан пропагандистської та агітаційномасової роботи в Бережанському і Підгаєцькому районах. Постанова фріксує низку позитивів: здійснюють теоретичні акції у формі бесід, консультацій індивідуального і групового характеру, працюють гуртки із вивчення історії ВКП(б) безпартійним активом, застосовують різноманітні форми агітаційно-масової роботи. Такі заходи дали конкретний результат, зокрема розгорнуто соціалістичне змагання між селами, колгоспами, районами, а Бережанський район завершив сівбу ранніх культур за 5 днів. До негативу в постанові віднесено фрактично один недолік: недостатня робота окремих комуністів над підвищенням свого ідейно-політичного рівня [7].

Буквально через три місяці, 23 серпня 1940 р., бюрообкомузновурозглядаєаналогічнепитанняпро виконання Бережанським райкомом КП(б)У травневої постанови бюро обкому щодо рівня пропагандистської та агітаційної роботи в районі. Хоча традиційно знаходиться місце для констатації позитивних моментів у роботі райкому партії та перелік недоліків призводить до висновку, що стан агітаційно-пропагандистської роботи в районі погіршився: відсутній контроль партійного комітету за вивченням комуністами і безпартійним активом історії ВКП(б), з цих питань не проводять індивідуальні бесіди, немає нарад з обміну досвідом роботи; слабка агітаційно-масова робота серед колгоспників, а в окремих колгоспах під час жнив припинили свою роботу агітатори, не організовано соціалістичного змагання; район потребує розширення лекційної пропаганди, особливо зусиллями кваліфікованих лекторів; необхідно пожвавити роботу агітаторів і агітколективів, забезпечити всебічну допомогу їх керівникам [2].

Отже, увага партійно-державних органів до культурно-масової та пропагандистсько-агітаційної роботи в трудових колективах міст і сіл особливо загострилась у період підготовки до виборів у Верховну Раду СРСР і Верховну Раду УРСР взимку - навесні 1940 р. Питання підготовки до проведення виборів у вищі органи державної влади СРСР та УРСР бюро обкому розглянуло на своєму засіданні 27 січня 1940 р. і наголосило, що «успіх виборчої кампанії залежатиме від того, як партійні організації забезпечать розгортання агітаційно-масової та політичної роботи серед широких трудящих мас». Для цього райкоми і міськкоми КП(б)У області були зобов'язані підготувати і затвердити на партійно-комсомольських зборах районів конкретні заходи із підготовки до виборів, в яких передбачити створення гуртків, проведення лекцій, бесід, доповідей для всіх виборців із вивчення Сталінської Конституції і положення про вибори до Верховних Рад СРСР та УРСР; підбір і формування агітколективів і груп агітаторів, проведення для них інструктивних нарад і семінарів не менше трьох разів на місяць і скликання нарад 3 обміну досвідом роботи; проведення трьох- і п'ятиденних семінарів для агітаторів із питань конституційного і виборчого законодавства; забезпечення агітпунктів на виборчих дільницях лозунгами, плакатами, діаграмами, що ілюструють досягнення Радянського Союзу і Радянської України; проведення районних нарад культпрацівників (завідуючих клубами, бібліотеками, хатами-читальнями) 3 питань їх роботи на період підготовки і проведення виборів; 
активізація роботи гуртків художньої самодіяльності, радіо, районних газет, інших засобів масової агітації; проведення зборів населення за місцем проживання 3 питань виборів; висвітлення виборчого процесу в місцевій пресі; проведення зборів молодих виборців [1].

На цьому ж бюро як взірець для райкомів і міськкомів партії області було схвалено заходи Тернопільського обкому КП(б)У із розгортання масовополітичної роботи в час підготовки і проведення виборів депутатів до Верховних Рад СРСР і УРСР по Тернопільській області. Заходи передбачали комплекс нарад із секретарями райкомів партії і райкомів комсомолу, головами райвиконкомів, завідуючими відділами пропаганди і агітації райкомів партії і райкомів комсомолу, завідуючими партійними кабінетами райкомів партії, головами і секретарями окружних виборчих комісій, головами обкомів галузевих профспілок із питань підготовки до виборів і проведення виборчої кампанії. Було заплановано обласний партійний актив «Про завдання обласної партійної організації в підготовці та проведенні виборів» та обласний профрспілковий актив з аналогічним порядком денним, обласну нараду редакторів районних газет «Завдання преси в час підготовки і проведення виборів до Верховних Рад СРСР і УРСР», обласний зліт робсількорів «Про завдання робсількорів у підготовці і проведенні виборів депутатів Верховних Рад СРСР і УРСР» (1500 чоловік).

\section{Висновки}

Згадані заходи стосувалися забезпечення впливу партійних органів області на виборчий процес у напрямі гарантування необхідного результату виборів, а інші заходи спрямовувалися безпосередньо на місцеве населення 3 метою максимального його залучення до виборчої кампанії через діяльність культосвітніх структур, через участь у культурно-масовій роботі з метою формування людини 3 соціалістичним світоглядом, покірливого виконавця наказів радянської системи.

Перспективи подальших досліджень можуть стосуватись глибшого і окремого вивчення трансорормаційних процесів у медицині, освіті та культурі краю тощо.

\section{Список літератури}

1. Про стан роботи Тарнопольського і Борщівського повітових комітетів КП(б)У : Постанова бюро Тарнопольського обкому КП(б)У від 13 січня 1940 року. - Ф. П-1, оп. 1, спр. 5. - Арк. 14-15.

2. Про стан пропагандистської та агітаційної роботи в Заліщицькому районі : Постанова бюро Тарнопольського обкому КП(б)У від 13 серпня 1940 року. - Ф. П-1, оп. 1, спр. 12. - Арк. 97.

3. Про стан пропагандистської і агітаційно-масової роботи в Бережанському та Підгаєцькому районах : Постанова бюро Тарнопольського обкому КП(б)У від 13 травня 1940 року. - Ф. П-1, оп. 1, спр. 9. - Арк. 187-188.

4. Про виконання Бережанським райкомом КП(б)У рішень обкому КП(б)У про організацію пропагандистської та агітаційної роботи в районі : Постанова бюро Тарнопольського обкому КП(б)У від 23 серпня 1940 р. - Ф. П-1, оп. 1, спр. 27. - Арк. 151-152.

5. Про підготовку до виборів у Верховну Раду СРСР і Верховну Раду УРСР : Постанова бюро Тарнопольського обкому КП(б)У від 3 лютого 1940 року. - Ф. П-1, оп. 1, спр. 6. - Арк. 117-118.

6. Про політичний стан у Збаразькому районі : Постанова бюро Тарнопольського обкому КП(б)У від 23 грудня 1939 року. - Ф. П-1, оп. 1, спр. 1. - Арк. 19-22.

7. Ковалюк В. Р. Культурологічні та духовні аспекти «радянізації» Західної України (вересень 1939 р. - червень 1941 р.) / В. Р. Ковалюк // Український історичний журнал. - 1993. - № 2, 3. - 10 с.

8. Соколовська Т. Г. Культурне будівництво у західних областях УРСР в перші роки радянської влади: вересень 1939 - червень 1941 рр. 40 років Великого Жовтня / Т. Г. Соколовська. - Львів : Видавництво Львівського університету, 1957. -227 c.

\section{References}

1. Postanova biuro Tarnopolskoho obkomu $\mathrm{KP}(\mathrm{b}) \mathrm{U}$ vid 13 sichnia 1940 roku "Pro stan roboty Tarnopolskoho $\mathrm{i}$ Borshchivskoho povitovykh komitetiv KP(b)U" [Resolution of the Bureau of the Tarnopol Regional Committee of the KP (b) U from January 13, 1940, "On the State of Ternopil and Borshchiv County Committees of the CP (b) U"]. Derzhavnyi arkhiv Ternopilskoi oblasti - State Archive of Ternopil region [in Ukrainian].

2. Postanova biuro Tarnopolskoho obkomu KP(b)U vid 13 serpnia 1940 roku "Pro stan propahandystskoi ta ahitatsiinoi roboty $v$ Zalishchytskomu raioni" [Resolution of the Bureau of the Tarnopol Regional Committee of the KP (b) $U$ from August 13, 1940, "On the State of Advocacy and Advertising in Zalishchytskyi District"]. Derzhavnyi arkhiv Ternopilskoi oblasti - State Archive of Ternopil region [in Ukrainian].

3. Postanova biuro Tarnopolskoho obkomu KP(b)U vid 13 travnia 1940 roku "Pro stan propahandystskoi i ahitatsiinomasovoi roboty $\vee$ Berezhanskomu ta Pidhaietskomu raionakh" [Resolution of the Bureau of the Tarnopol Regional Committee of the KP (b) $U$ of May 13, 1940, "On the State of Advocacy and Mass Media in Berezhany and Pidhaitsi Districts"]. Derzhavnyi arkhiv Ternopilskoi oblasti - State Archive of Ternopil region [in Ukrainian].

4. Postanova biuro Tarnopolskoho obkomu KP(b)U vid 23 serpnia 1940 r. "Pro vykonannia Berezhanskym raikomom $\mathrm{KP}(\mathrm{b}) \cup$ rishen obkomu $\mathrm{KP}(\mathrm{b}) \cup$ pro orhanizatsiiu propahandystskoi ta ahitatsiinoi roboty $v$ raioni" [Resolution of the Bureau of the Tarnopol Regional Committee of the KP (b) $U$ dated August 23, 1940 "On the implementation of the Berezhanskyi 
district committee of the $\mathrm{CP}(\mathrm{b})$ In the decisions of the regional committee of the $\mathrm{KP}(\mathrm{b}) \mathrm{U}$ on the organization of propaganda and propaganda work in the area"]. Derzhavnyi arkhiv Ternopilskoi oblasti - State Archive of Ternopil region [in Ukrainian]. 5. Postanova biuro Tarnopolskoho obkomu KP(b)U vid 3 liutoho 1940 roku "Pro pidhotovku do vyboriv u Verkhovnu Radu SRSR i Verkhovnu Radu URSR" [Resolution of the Bureau of the Tarnopol Regional Committee of the KP (b) U of February 3, 1940 "On the Preparation for the Elections to the Verkhovna Rada of the USSR and the Verkhovna Rada of the Ukrainian SSR"]. Derzhavnyi arkhiv Ternopilskoi oblasti - State Archive of Ternopil region [in Ukrainian].

6. Postanova biuro Tarnopolskoho obkomu KP(b)U vid 23 hrudnia 1939 roku "Pro politychnyi stan u Zbarazkomu raioni [Resolution of the Bureau of the Tarnopol Regional Committee of the KP (b) U of December 23, 1939, "On the Political Status in Zbarazh District"]. Derzhavnyi arkhiv Ternopilskoi oblasti - State Archive of Ternopil region [in Ukrainian].

7. Kovaliuk, V.R. (1993). Kulturolohichni ta dukhovni aspekty "radianizatsii" Zakhidnoi Ukrainy (veresen 1939 r. - cherven 1941 r.) [Cultural and spiritual aspects of "Sovietization" of Western Ukraine (September 1939 - June 1941)]. Ukrainskyi istorychnyi zhurnal - Ukrainian Historical Journal, 2-3, 10 [in Ukrainian].

8. Sokolovska, T.H. (1957). Kulturne budivnytstvo u zakhidnykh oblastiakh URSR v pershi roky radianskoi vlady: veresen 1939 - cherven 1941 rr.40 rokiv Velykoho Zhovtnia [Cultural construction in the western regions of the Ukrainian Soviet Socialist Republic in the early years of Soviet power: September 1939 - June 1941.40 years of the Great October]. Lviv: Vydavnytstvo Lvivskoho universytetu [in Ukrainian].

\section{ТРАНСФОРМАЦИОННЫЕ ПРОЦЕССЫ НА ТЕРНОПОЛЬЩИНЕ В 1939-1940 ГОДАХ КАК ФАКТОР ФОРМИРОВАНИЯ У СТУДЕНТОВ-МЕДИКОВ ЧУВСТВА ПАТРИОТИЗМА, КОМПЕТЕНТНОСТИ В ХОДЕ ИЗУЧЕНИЯ ИСТОРИИ КРАЯ}

Л. В. Кравчук, Т. Б. Кадобный, Л. А. Кравчук

ГВУЗ «Тернопольский государственный медицинский университет имени И. Я. Горбачевского МЗ Украины», г. Тернополь, Украина

Цель: путем анализа общественно-политических и социально-экономических трансформационных процессов на Тернопольщине в 1939-1941 гг. и их последствий фрормировать у студентов-медиков чувства патриотизма, компетентности в ходе программного изучения новейшей истории Украины.

Материалы и методы. На основе историко-сравнительного и библиосемантичного методов проведено систематический анализ научных источников отечественных исследователей и историков диаспоры, архивных материалов по информации о событиях предвоенного периода на территории Тернопольщины.

Результаты. В предлагаемой статье авторами раскрыта природа и мотивы новой советской власти, которая с оружием вступила на территорию Украины 17 сентября 1939 г. и путем насилия вводила свои реформы местному населению. Установлено, что мнения исследователей расходятся в трактовке освободительного похода Красной армии на запад и виявлено взаимосвязь общих государственных и региональных фракторов советизации Тернопольщины.

Выводы. Авторами сделано собственный вклад в раскрытие мотивов и последствий деятельности тогдашней советской власти на территории края.

КЛЮЧЕВЫЕ СЛОВА: Западная Украина; Тернопольская область; советская власть; культура; режим; оккупация.

\section{TRANSFORMATION PROCESSES IN TERNOPIL REGION IN 1939-1941 AS A FACTOR OF FORMATION THE FEELING OF PATRIOTISM AND COMPETENCE OF MEDICAL STUDENTS DURING THE LEARNING OF THE HISTORY OF THE REGION}

L. V. Kravchuk, T. B. Kadobnyi, L. O. Kravchuk

I. Horbachevsky Ternopil State Medical University, Ternopil, Ukraine

Purpose: to form the feeling of patriotism and competence of medical students during the programmatic study of the modern history of Ukraine through the analysis of socio-political, socio-economic transformational processes in Ternopil region in 1939-1941 and their consequences.

Materials and Methods. On the basis of historical-comparative and bibliosemantic methods, systematic analysis of scientific sources of domestic researchers and diaspora historians, archival materials, concerning information about the events of the pre-war period on the territory of Ternopil region, was carried out.

Results. In the proposed article, the authors disclose the nature and motives of the new Soviet government, which occupied the territory of Western Ukraine on September 17, 1939, and through violence introduced its reforms to the local population. It is established that the opinions of the researchers diverge in the interpretation of the Red Army liberation campaign in the west and the relationship between the general state and regional factors of Soviet reforms in Ternopil region.

Conclusion. The authors made their own contribution to the disclosure of the motives and consequences of the former Soviet power in the territory.

KEY WORDS: Western Ukraine; Ternopil region; Soviet power; culture; regime; occupation. 
Відомості про авторів:

Кравчук Леонід Васильович - кандидат історичних наук, доцент кафедри педагогіки вищої школи ДВНЗ «Тернопільський державний медичний університет імені І. Я. Горбачевського МОЗ України»; тел.: +38(0352) 43-11-68.

Кадобний Тарас Богданович - кандидат фрілософських наук, доцент кафредри педагогіки вищої школи ДВНЗ «Тернопільський державний медичний університет імені І. Я. Горбачевського МОЗ України»; тел.: +38(0352) 43-11-68.

Кравчук Лариса Олександрівна - кандидат біологічних наук, доцент кафредри загальної хімії ДВНЗ «Тернопільський державний медичний університет імені І. Я. Горбачевського МОЗ України»; тел.: +38(0352) 52-43-37. 